\title{
Tinjauan Pelaksanaan Kerahasiaan Rekam Medis Di Puskesmas Kuranji Padang
}

\author{
Deni Maisa Putra ${ }^{1}$, Rahmadhani
}

${ }^{1,2}$ D3 Study Program Medical Record and Health Information, STIKes Dharma Landbouw Padang

\begin{tabular}{l} 
Article Info \\
\hline Article history: \\
Received Dec 28, 2020 \\
Revised Feb 17, 2021 \\
Accepted Feb 19, 2021 \\
\hline
\end{tabular}

Keywords:

Confidentiality

Medical Records

Knowledge

Attitude

\begin{abstract}
ABSTRAK
The medical record is also a documentation of the patient's condition and the contents of the medical record are medical secrets, especially in the storage of status in the filling room, which must be kept confidential, secure, and the medical record layout, whether it is appropriate or not by every health worker. The purpose of this study was to determine the Knowledge Review and Attitudes of Officers and Patients on the Confidentiality of Medical Record Files Primary Health Center at Kuranji Padang. This type of research is descriptive with a quantitative approach, the research sample is 90 patients and 4 health center officers using accidental sampling technique with data collection using questionnaires for patients and table cklis for officers. The results showed that there are still officers whose knowledge and attitude in maintaining the confidentiality of medical records $(50 \%)$ or 2 people are still lacking in knowledge $(51.1 \%)$ and attitudes $(52.2 \%)$ of patients towards maintaining the confidentiality of record files medical who do not understand and know. It can be concluded that Kuranji Primary Health Center, both patients and officers, is still lacking in maintaining the confidentiality of medical records. It is hoped that the head of the Primary Health Center will prepare Standard Operating Procedures (SOP) on medical records so that officers and patients know about medical records and about the confidentiality of medical records. In implementing the confidentiality of medical records, competent and professional medical record officers should know and understand more about medical records, participate in training and provide information to patients so that the confidentiality of medical records is maintained and can create good service.
\end{abstract}

\section{Corresponding Author:}

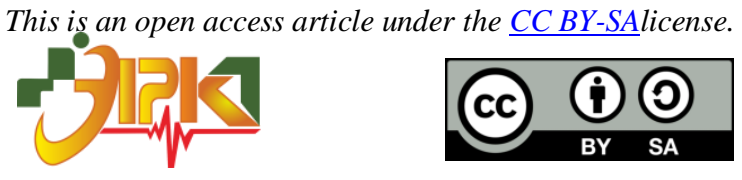

Deni Maisa Putra,

D3 Study Program Medical Record and Health Information,

STIKes Dharma Landbouw Padangs,

Jl. Jhoni Anwar No 29 UlakKarang Padang, Sumatera Barat.

Email: denimaisaputra@gmail.com

\section{PENDAHULUAN}

Pelayanan kesehatan merupakan setiap upaya yang diselenggarakan sendiri atau secara bersama dalam kegiatan organisasi supaya kesehatan dapat meningkatkan dan terpelihara, menyembuhkan dan mencegah penyakit agar kesehatan setiap orang dan keluarga, 
kelompok ataupun masyarakat. Upaya dalam peningkatan kesehatan dalam pelayanan di puskesmas dan di rumah sakit tidak akan berjalan baik bila faktor eksternal tidak mendukung ${ }^{1}$.

Puskesmas merupakan suatu unit pelaksanaan fungsional yang berperan sebagai pusat pembangunan dibidang kesehatan masyarakat, pusat binaan masyarakat dalam bidang kesejahteraan kesehatan yang dipentingkan dalam kondisi fisik manusia, dan sebagai pelayanan kesehatan tingkat pertama, terpadu berkesinambungan, yang melaksanakan kegiatannya secara berkesinambungan dan terpadu pada suatu masyarakat yang berdomisili dalam suatu wilayah tertentu, dalam suatu keputusan menteri kesehatan dapat memberikan suatu keadaan yang baik dan dapat menjadikan suatu perumusan dalam pengertian puskesmas ${ }^{2}$.

Setiap Puskesmas diwajibkan menyelenggarakan rekam medis sebagai bukti penyelenggaraan kesehatan yang dilakukan di puskesmas. Rekam medis adalah salah satu catatan pasien tertulis merupakan golongan arsip vital dalam pelaporan. Arsip vital merupakan suatu berkas yang keberadaanya tidak dapat dirubah, dan tidak dibuat ulang apabila terjadi kerusakan, terbakar atau hilang dan sering disebut arsip kelas satu ${ }^{3}$.

Rekam Medis sanga trahasia (strictly medical confidential), karena rekam medis berisi catatan penting tentang kondis pasien dan tidak boleh disebarluaskan, informasi yang mengandung kerahasianya itu laporan atau catatan yang terdapat dalam berkas rekam sebagai hasil pemeriksaan, pengobatan, dilihat dari segi psikologis pasien tidak senang jika penyakitnya diketahui orang lain, apabila suatu penyakit yang penting dijaga kerahasiaannya oleh masyarakat seperti penyakit gangguan jiwa dan penyakit kelamin, paru-paru, kista dan sebagainya. Kerahasiaan rekam medis tidak terbatas pada data medis saja tetapi juga terhadap data identitas dokter maupun pasien antara lain, nama, alamat rumah, alamat kantor, dan lain-lain, karena keterangan tersebut memungkinkan dapat disalahgunakan untuk tujuan yang merugikan pasien maupun staf medik. Data terkait identitas, riwayat penyakit, diagnosis, riwayat pemeriksaan, dan riwayat pengobatan klien harus terjaga kerahasiannya oleh dokter, tenaga kesehatan, dokter gigi, petugas pengelola, dan pimpinan sarana pelayanan kesehatan, yang berbunyi alam pasal 10 ayat (1) Permenkes RI Nomor 269/Menkes/Per/III/2008 4.

Rekam medis juga merupakan salah satu bukti yang dapat dipergunakan dalam pembuktian perkara kasus malpraktek di pengadilan. Rekam medis juga salah satu bagian dokumentasi keadaan klien dan isi data rekam medis merupakan bukti catatan rahasia dokter terutama dalam penyimpanan status didalam ruangan filling, yang harus dijaga kerahasian, keamanan, tata letak rekam medis, apakah itu layak atau tidaknya oleh setiap tenaga kesehatan, agar dokumen rekam medis tertata dan tersusun dengan baik oleh petugas rekam medis sehingga terlindungi dari hal-hal yang bisa membocorkan isi dan pencurian dokumen ${ }^{5}$.

Sistem pengerjaan rekam medis di indonesia dilaksanakan dalam unit rekam medis meliputi filling. Filling yaitu ruangan yang digunakan untuk menyimpan berkas rekam medis dan penyimpanan dokumen rekam medis, dan pengambilan kembali rekam medis dengan tujuan untuk mempermudah dan mempercepat ditemukan kembali dokumen yang disimpan, serta melindungi dokumen dari bahaya pencurian, dan juga bahaya kerusakan fisik, kimiawi dan biologi, dan dalam proses pengambilannya dari rak penyimpanan lebih mudah ${ }^{6}$

Fiiling memiliki peranan dalam hal penyimpanan sampai perlindungan dan kerahasiaan dokumen rekam medis. Penyimpanan dokumen data rekam medis berjalan dengan baik dan bagus memiliki fasilitas penunjang seperti rak rekam medis tidak terlalu tinggi sesuai dengan keadaan petugas yang mudah dijangkau untuk pengambilan dokumen, selain rekam medis terkelola dengan baik dan rapi hal tersebut dapat memperlancar proses penyimpanan dan pengambilan dokumen rekam medis. 
Menurut PERMENKES No,269 MENKES/PER/III/2008 pasal 7 BAB III, tentang rekam medis dikatakan disetiap sarana kesehataan yang menyediakan fasilitas untuk menunjang ketersediaan rekam medis perlu dilakukan pemantauan penyelenggarakan rekam medis yang bermutu. Rekam medis diselenggarakan oleh pengelola Rekam Medis diantaranya adalah filing tempat untuk penyimpanan data dokumen rekam medis ${ }^{7}$.

Berdasarkan survey yang peneliti lakukan, bahwa Puskesmas Kuranji telah menjalankan tugasnya sebagai pelayanan kesehatan masyarakat yang baik dan memberikan pengobatan pada pasien, penulis mengambilan data di Puskesmas Kuranji Padang karena disana belum terjaganya kerahasiaan dan keamanan rekam medis. Selain itu petugas yang ada dibagian rekam medis bukan ahli madya rekam medis, melainkan dari tamatan bidan, berbeda dengan beberapa puskesmas lain telah terjaga keamanan dan kerahasiaannya karena di puskesmas lain petugas yang bertugas telah mengetahui tentang keamanan dan kerahasiaan rekam medis dan juga lulusan rekam medis.

Selain itu peneliti juga menemukan petugas medis dan non medis yaitu perawat, tukang kebersihan, dan keluaga pasien yang dapa tmemasuki ruangan rekam medis tanpa izin dari petugas rekam medis, berdasarkan denah ruangan filling berdekatan langsung pada tempat pendaftaran sehingga memudahkan orang yang tidak berkepentingan itu masuk kedalam ruangan filling, dan pintu sering tidak terkuci. Puskesmas Kuranji Padang semua pasien yang berobat kepoliklinik membawa sendiri berkas rekam medis miliknya, hal ini disebabkan tidak adanya pengetahuan petugas tentang pentingnya keamanan dan kerahasiaan dan didasari oleh kondisi fisik puskesmas yang tidak menggunakan jasa kurir yang mengantar rekam medis kepoli di puskesmas tersebut, dan kurangnya pengelola unit rekam medis yang bekerja dibagian rawat jalan. Berdasarkan uraian dan paparan di atas maka peneliti tertarik untuk melakukan penelitian tentang "Tinjauan Pelaksanaan Kerahasiaan Rekam Medis Di Puskesmas Kuranji Padang Tahun 2019”.

\section{METODE PENELITIAN}

A. Jenis Penelitian

Penelitian ini merupakan penelitian kuantitatif dan desain penelitian menggunakan acciental sampling yaitu teknik non random sampling, dimana pengambilan sampel dilakukan dengan mengambil kasus atau respondem yang kebetulan ada atau tersedia.

B. Waktu dan Tempat Penelitian

Pelaksanaan penelitian ini dimulai pada bulan Maret s/d Mai Tahun 2019, Tempat penelitian ini telah dilakukan di Puskesmas Kuranji Kota Padang Sumatra Barat.

C. Populasi dan Sampel

Populasi merupakan generalisasi yang terdiri atas obyek/subyek yang memmiliki karakteristik dan kualitas tertentu yang ditentukan oleh peneliti agar dipahami, dipelajari dan kemudian ditarik kesimpulannya, jadi populasi bukan hanya orang, tetapi juga obyek dan benda alam lainnya ${ }^{8}$. Sehingga populasi dari penelitian ini adalah petugas rekam medis 4 orang dan pasien yang berkunjung pada instalasi rawat jalan sebanyak 90 orang.

D. Definisi Operasional

Variabel yang diteliti/diamati hendaknya perlu sesekali variabel-variabel tersebut diberi batasan atau definisi operasional ${ }^{9}$. Dengan memperhatikan perumusan masalah dan latar belakang, maka definisi operasional variabel dari penelitian ini adalah sebagai berikut:

1. Pengetahuan pasien yaitu segala yang diketahui oleh pasien terhadap pentingnya menjaga kerahasiaan rekam medis.

2. Pengetahuan petugas yaitu segala sesuatu yang diketahui oleh petugas terhadap 
pentingnya menjaga kerahasiaan.

3. Sikap petugas merupakan tanggapan petugas terhadap sesuatu yang diketahuinya akan berkas rekam medis milik pasien terhadap hal-hal yang berkaitan dengan kerahasiaan berkas rekam medis itu sendiri.

4. Sikap pasien merupakan tanggapan pasien terhadap sesuatu yang diketahuinya akan berkas rekam medis miliknya terhadap hal-hal yang berkaitan dengan kerahasiaan berkas rekam medis

E. InstrumenPenelitian

Alat yang digunakan dalam melakukan penelitian ini yaitu dengan menggunakan kuesioner dan table cheklis, untuk mengetahui pengetahuan, sikap pasien dan petugas, pentingnya menjaga kerahasiaan rekam medis di Puskesmas Kuranji Padang.

F. Tehnik Pengolahan dan Analisis Data

Pengolahan data yang dilakukan melalui tahapan proses. Data diolah secara komputerisasi dengan tahapan sebagai berikut:

\section{Editing}

Data yang telah dikumpulkan kemudian diperiksa bila terdapat kesalahan dalam mengumpulkan data, data diperbaiki dengan melengkapi jawaban yang kurang.

2. Coding

Coding adalah usaha pengklasifikasian jawaban menurut kriteria tertentu, dimana jawaban responden diklasifikasikan dengan kode angka. Guna coding adalah untuk mempercepat dan mempermudah pada saat analisis data dan juga pada saat entri data.

3. Entri Data

Setelah data diedit dan di coding, kemudian dilakukan pengentrian data dengan bantuan komputerisasi.

4. Cleaning Data

Pembersihan data dilakukan untuk mengetahui jika terdapat kesalahan dalam proses pengentrian data yang telah dimasukan.

Analisis data dalam penelitian ini menggunakan data kuantitatif. Analisis data yakni serangkaian kegiatan untuk mengolah data dari seluruh responden atau sumber data lain terkumpul. Proses analisis data yaitu menyajikan data tiap variabel yang diteliti, mengelompokkan berdasarkan variabel dan jenis responden, melakukan perhitungan untuk menguji hipotesis yang telah di ajukan, melakukan perhitungan untuk menjawab rumusan masalah ${ }^{8}$.

\section{HASIL DAN PEMBAHASAN}

\subsection{Hasil}

Pengumpulan data dilakukan wilayah kerja Puskesmas Kuranji Padang dengan jumlah partisipan sebanyak 90 pasien dan 4 orang petugas. Penelitian ini dilakukan menggunakan kuesioner dan tabel ceklis melalui wawancara kepada pasien dan petugas yang ada di Puskesmas. Analisis univariat bertujuan menjelaskan dan mendeskripsikan karakteristik variabel penelitian dan mengetahui distribusi frekuensi darisetiap variabel masing-masing penelitian (variabel independen dan variabel dependen) dan memperoleh hasil sebagai berikut:

\section{Pengetahuan Petugas Terhadap Menjaga Kerahasiaan Rekam Medis}

Dari jumlah responden 94 orang yang diteliti, diantaranya 90 pasien rekam medis dan 4 petugas rekam medis, untuk melihat sikap pasien dan petugas tentang Tinjauaan Pelaksanaan Kerahasiaan Berkas Rekam Medis diperoleh sebagai berikut: 
Tabel 1. Distribusi Frekuensi Pengetahuan Petugas Terhadap Menajaga Kerahasiaan Rekam Medis

\begin{tabular}{ccc}
\hline Pengetahuan Petugas & $\boldsymbol{F}$ & $\boldsymbol{\%}$ \\
\hline Kurang & 2 & 50,0 \\
\hline Cukup & 1 & 25,0 \\
\hline Baik & 1 & 25,0 \\
\hline Total & $\mathbf{4}$ & $\mathbf{1 0 0 , 0}$
\end{tabular}

Berdasarkan tabel diatas di dapatkan bahwa dari 4 orang sampel, pengetahuan petugas dalam menjaga kerahasiaan rekam medis terdapat 2 petugas yang kurang dalam mengetahui kerahasiaan rekam medis karena petugas tersebut tidak dari tamatan rekam medis, yang kurang sebesar 50,0\%.

Pengetahuan Pasien Terhadap Menjaga Kerahasiaan Rekam Medis

Tabel 2. Distribusi Frekuensi Pengetahuan Pasien Terhadap Menjaga Kerahasiaan Rekam Medis

\begin{tabular}{ccc}
\hline Pengetahuan Pasien & $\boldsymbol{f}$ & \% \\
\hline Kurang & 46 & 51,1 \\
\hline Cukup & 27 & 30,0 \\
\hline Baik & 17 & 18,9 \\
\hline Total & $\mathbf{9 0}$ & $\mathbf{1 0 0 , 0}$ \\
\hline
\end{tabular}

Berdasarkan tabel diatas di dapatkan bahwa dari 90 pasien yang dijadikan sampel pengetahuan pasien dalam menjaga kerahasiaan rekam medis yang kurang sebanyak 46 pasien atau sebanyak $51,1 \%$.

Sikap Petugas Terhadap Menjaga Kerahasiaan Berkas Rekam Medis Tabel 3. Distribusi Frekuensi Sikap Petugas Terhadap Menjaga Kerahasiaan Rekam Medis

\begin{tabular}{ccc}
\hline Sikap Petugas & $\boldsymbol{f}$ & $\boldsymbol{\%}$ \\
\hline Tidak Baik & 2 & 50,0 \\
\hline Baik & 2 & 50,0 \\
\hline Total & $\mathbf{4}$ & $\mathbf{1 0 0 , 0}$
\end{tabular}

Berdasarkan tabel diatas di dapatkan bahwa dari 4 orang sampel, sikap petugas dalam menjaga kerahasiaan rekam medis terdapat 2 petugas yang mengarah ke yang tidak baik dalam menjaga kerahasiaan berkas rekam medis, atau sebesar 50,0\%.

Sikap Pasien Terhadap Menjaga Kerahasiaan Berkas Rekam Medis

Tabel 4. Distribusi Frekuensi Sikap Pasien Terhadap Menjaga Kerahasiaan Rekam Medis

\begin{tabular}{ccc}
\hline Sikap Pasien & $\boldsymbol{f}$ & \% \\
\hline Tidak Baik & 43 & 47,8 \\
\hline Baik & 47 & 52,2 \\
\hline Total & 90 & 100,0 \\
\hline
\end{tabular}

Berdasarkan tabel diatas di dapatkan bahwa dari 90 orang sampel sikap pasien dalam menjaga kerahasiaan berkas rekam medis terdapat sikap pasien yang baik sebanyak $52,2 \%$.

\subsection{Pembahasan}

Pengetahuan Petugas Terhadap Menjaga Kerahasiaan Berkas Rekam Medis

Berdasarkan hasil pengukuran univariat di dapatkan pengetahuan petugas terhadap menjaga kerahasiaan berkas rekam medis di Puskesmas Kuranji Padang, pengetahuan 
petugas yang kurang sebesar 2 (50,0\%), pengetahuan petugas yang cukup 1 (25,0\%), dan yang baik $1(25,0 \%)$. Pengetahuan petugas rekam medis salah satunya adalah usia, dalam penelitian ini rata-rata responden berusia 13-70 Tahun sebanyak 4 orang ${ }^{10}$.

Rekam medis adalah ringkasan tertulis terkait fakta perjalanan kehidupan dan kesehatan pasien, penyakit lama dan penyakit sekarang serta proses pengobatan yang ditulis oleh tenaga kesehatan yang melayani pasien tersebut. Pengetahuan yang dimiliki petugas rekam medis akan meningkatkan motivasi petugas dalam mendokumentasikan data-data dan keluhan pasien dalam rekam medis sehingga menunjang tercapainya tertib administrasi.

Pengetahuan yang harus dimiliki petugas terhadap kerahasiaan rekam medis sangatlah penting, karena akan berpengaruh terhadap informasi yang akurat. Oleh karena itu petugas rekam medis diharapkan untuk dapat meningkatkan pengetahuan dalam hal kerahasiaan rekam medis dengan pengetahuan petugas yang baik terhadap rekam medis diharapkan kepada pimpinan puskesmas pada rekam medis sebaiknya diberikan pengarahan dan pelatihan terhadap petugas agar petugas rekam medis mengetahui semua yang menyangkut tentang rekam medis.

Berdasarkan hasil data kuesioner yang dibagikan oleh peneliti terhadap petugas dan diisi langsung oleh petugas, pernyataan petugas yang bernilai banyak salah dibagian pertanyaan pada kerahasiaan rekam medis yag bersifat rahasia banyak petugas yang tidak mengetahui tentang rekam medis, sedangkan pernyataan yang diisi oleh petugas yang bernilai banyak benar pada pengetahuan petugas tentang penghapusan tulisan yang ada di berkas rekam medis. Pada hasil penelitian ditemukan pengetahuan petugas rekam medis yang memperbolehkan pasien dan clining servis masuk kedalam ruangan penyimpanan rekam medis, clining servis tersebut sambil membantu petugas rekam medis dan juga di waktu luang petugas clining servis tidur di ruangan rekam medis, terlihat sebagian petugas rekam medis dan pasien belum terlalu memahami apa itu rekam medis, dengan tidak paham nya petugas tentang rekam medis maka berpengaruh terhadap kerahasian rekam medis, rendahnya tingkat pengetahuan petugas rekam medis terhadap kerahasiaan rekam medis disebabkan kurang pengalaman dan informasi tentang rekam medis dan juga petugas yang berda di ruangan rekam medis bukan tamatan dari perguruan tinggi dan tidak tamatan dari jurusan rekam medis, petugas hanya tamatan SMA, dan dari tamatan jurusan kebidanan.

\section{Pengetahuan Pasien Terhadap Menjaga Kerahasiaan Berkas Rekam Medis}

Berdasarkan tabel diatas di dapatkan bahwa dari 90 orang sampel pengetahuan pasien dalam menjaga kerahasiaan rekam medis pasien yang kurang $46(51,1 \%)$, yang cukup sebesar 27 (30,0\%), dan yang baik sebesar $17(18,9 \%)$, alat ukur yang digunakan oleh peneliti masih menggunakan kuesioner pada hasil penilaian kuesioner yang diisi lansung oleh pasien terdapat pernyataan salah terdapat pada pengetahuan pasien tentang isi rekam medis yang disebar luaskan oleh seseorang dan pasien banyak memilih membiarkan nya saja dan tidak membawa ke jalur hukum, semua itu disebabkan karna kurang pahamnya pasien terhadap kerahasiaan berkas rekam medis,sedangkan pernyataan yang benar tentang pengetahuan pasien terhadap bagaimana pasien dalam menjaga berkas rekam medis saat berada didalam genggaman pasien.

Hasil penelitian ini juga dikemukakan oleh Ramadhaniyah tentang kerahasian rekam medis dilihat dari tingkat pengetahuan yang memiliki pengetahuan yang tau sebanyak 28 $(70,0 \%)$ dan tingkat pengetahuan yang tidak tau $12(30,0 \%){ }^{11}$. Lebih separoh yang tidak tau tentang kerahsiaan, dan juga dibahas oleh Dewi Novita ${ }^{12}$ pengetahuan perawat tentang kerahasiaan berkas rekam medis, sebanyak 22 orang $(55,0 \%)$ mempunyai pengetahuan tidak baik dalam menjaga kerahasiaan berkas rekam medis disebabkan kurangnya pengetahuan tentang rekam medis. 
Indera yang dimiliki oleh manusia seperti mata, hidung, telinga, dan otak merupakan objeku ntuk menumbuhkan pengetahuan yang dimilikinya. Dengan sendirinya, pada waktu pengindraan sampai mengahasilkan persepsi terhadap objek pengetahuan sangat dipengaruhi oleh intensitas perhatian setiap manusia ${ }^{9}$.

Penyebaran kuesioner peneliti menemukan masih banyak pasien yang tidak mengetahui kerahasiaan rekam medis, disebabkan karena pasien belum sepenuhnya mengetahui rekam medis, seharusnya pasien harus memahami betul apa itu rekam medis dan bisa membedakan rekam medis itu bersifat rahasia atau tidak rahasia, dimasa yang akan datang diharapkan tenaga rekam medis di berikan arahan dan pengetahuan tentang rekam medis kepada pasien yang berkujung di puskesmas.

\section{Sikap Petugas Terhadap Menjaga Kerahasiaan Rekam Medis di Puskesmas Kuranji Padang}

Berdasarkan hasil pengukuran univariat di dapatkan sikap petugas terhadap menjaga kerahasiaan rekam medis di puskesmas kuranji padang sikap petugas yang tidak baik 2 $(50,0 \%)$, baik sebesar $2(50,0 \%)$. Sikap merupakan reaksi atau respon yang masih tertutup dari seseorang terhadap suatustimulus atau objek upaya untuk meningkatkan atau merubah sikap negatif dari individu-individu agar bisa bersikap positif ${ }^{9}$.

Pada penelitian yang dilakukan peneliti, komponen utama sikap pada responden (petugas rekam medis) yaitu bagaimana sikap dari petugas saat menjaga kerahasiaan berkas rekam medis haruslahmelilikikesadaran, perilaku dan perasaanuntuk mengetahui bagaimana sikap dari perilaku untuk mengetahui terhadap kerahasiaan rekam medis ${ }^{11}$.

Alat ukur yang digunakan untuk penelitian ini yaitu dengan menggunakan tabel ceklis dengan pengamatan lansung yang dilakukan peneliti terhadap sikap petugas yang kurang baik terdapat di tabel cklis pada bagian ruangan rekam medis yang bebas dimasuki oleh orang lain seperti keluarga pasien dan pernyataan sikap yang baik yaitu tentang petugas yang harus menjaga berkas rekam medis yaitu petugas rekam medis, pada saat penelitian peneliti juga menemukan sebagian tenaga kesehatan yang belum memahami kerahasiaan rekam medis dan masih ditemukannya tenaga rekam medis yang memperbolehkan orang lain seperti pasien dan clining servis memasuki ruangan penyimpanan rekam medis tanpa izin, untuk mengubah sikap tenaga kesehatan yang masih kurang baik menjadi baik diperlukan kerja sama semua pihak petugas rekam medis baik dari pimpinan maupun dari dalam diri tenaga kesehatan itu sendiri. Pimpinan Puskesmas bisa memberikan sanksi berupa teguran dan memberikan pelatihan terhadap petugas terhadap petugas rekam medis yang masih memiliki sikap yang kurang baik terhadap kerahasiaan dan adanya pengawasan yang lebih ketat agar terjaga kerahasiaaan rekam medis.

\section{Sikap Pasien Dalam Menjaga Kerahasiaan Rekam Medis di Puskesmas Kuranji Padan}

Berdasarkan hasil pengukuran univariat di dapatkan sikap pasien terhadap menjaga kerahasiaan rekam medis di puskesmas kuranji padang sikap pasien yang tidak baik 43 $(47,8 \%)$, sedangkan yang baik $47(52,2 \%)$, alat ukur yang dilukan peneliti dalam sikap pasien masih menggunakan tabel ceklis dimana penilaian yang banyak salah terdapat pada bagian informasi rekam medis yang mengandung rahasia tidak terlalu penting dijaga kerahasiaannya, ruangan berkas rekam medis yang sangat sempit dan pintu rekam medis yang sering kebuka seakan hal itu bisa berpengaruh terhadap kerahasiaan yang tidak penting dijaga, sedangkan penilaian yang banyak benar terdapat pada bagian petugas kesehatan bertanggung jawab terhadap berkas rekam medis.

(Alport, 1954) menjelaskan bahwa sikap mempunyai tiga komponen, yaitu kepercayaan (keyakinan), iden dan konsep terhadap satu konsep yakni evaluasi emosional 
dan atau kehidupan emosional terhadap suatu objek serta kecendrungan untuk bertindak. Ketiga komponen ini secara bersama-sama membentuk sikap yang utuh, dalam penentuan sikap ini, pengetahuan, pemikiran, keyakinan dan emosi memegang peraan pentian.

Hal ini hampir sesuai dengan hasil penelitian lain bahwa sikap positif juga dipengaruhi oleh pengetahuan yang rendah sebanyak $(55,0 \%)$ karena kurang nya tingkat pendidikan dan perilaku memenuhi tingkatan kerahasiaan berkas rekam medis ${ }^{11}$. Dan hasil penelitian lain juga membahas bahwa sikap petugas dalam menjaga kerahasiaan rekam medis baik sebanyak 4 orang $(66,7 \%)$, sedangkan tidak baik sebanyak 2 orang $(33,3 \%)$, hasil penelitian menunjukakan bahwa petugas dengan kinerja untuk mengukur faktor perilaku tersebut di tentukan oleh pengetahuan dan sikap. Sikap merupakan respon seseorang terhadap suatu stimulus atau objek tertentu, yang sudah melihatkan emosi dan faktor bersangkutan. Sikap bisa menjadikan seseorang mengarah kecenderungan dari diri individu untuk berprilaku dengan pola tertentu. Sikap bisa diartikan reaksi atau respons yang masih tertutup terhadap suatu stimulus. Manifestasi terhadap sikap dapat ditafsirkan namun tidak dapat dilihat ${ }^{13}$.

Dari hasil ukur yang dilukan peneliti dalam sikap pasien dalam menjaga kerahasiaan berkas menggunakan tabel ceklis dimana penilaian terhadap sikap pasien masih bayak dikarekan berkas setelah pasien mendaftar terkadang berkas tersebutd ibawa oleh pasien itus endiri. Hal inilah perlu disadari oleh petugas agar berkas tersebut hendaknya diantarkan oleh petugas kepoli atau kepelayanan yang dituju agar kerahasiaan tersebut terjaga, dan tidak diketahui oleh pasien lainnya. Perlunya pengawasan oleh kepala Puskesmas atau Ka.instalasi rekam medis untuk selalu memantau terhadap berkas-berkas yang dibawa sendiri oleh pasien atau keluarga pasien, perlunya SOP yang megatur terkait berkas yang akan di distribusikan kepoli-poli atau unit pelayanan pasien tersbut, dan memberikan teguran lisan atau tulisan bagi petugas yang mengabaikan aturan yang berlaku demi menjaga kerahasian rekam medis tersebut.

\section{KESIMPULAN}

Berdasarkan hasil penelitian yang telah dilakukan pada 90 pasien dan 4 petugas yang ditemukan dilapangan, maka diperoleh kesimpulan sebagai berikut:

1. Separoh pengetahuan petugas terhadap menjaga kerahasian rekam medis yang kurang sebanyak $2(50,0 \%)$ di Puskesmas Kuranji Padang.

2. Lebih dari separoh pengetahuan pasien terhadap menjaga kerahasiaan berkas rekam medis sebanyak $46(51,1 \%)$ masih dikategorikan kurang di Puskesmas Kuranji Padang.

3. Kurang dari separoh sikap petugas yang tidak menjaga kerahasiaan berkas rekam medis sebanyak 2 (50,0\%) di Puskesmas Kuranji Padang.

4. Lebih dari separoh sikap pasien terhadap menjaga kerahasiaan rekam medis medis sebanyak 47 (52,2\%) tidak baik di Puskesmas Kuranji Padang.

\section{REFERENCES}

1. DepKes RI. Pedoman Penyelenggaraan Informasi Kesehatan di Sarana Pelayanan Kesehatan Rumah Sakit Indonesia. Dir Joktorat Jendral Bina Pelayanan Medic, Jakarta. In: ; 2009.

2. Azwar A. Pengantar Administrasi Kesehatan Edisi Ketiga. Binapura Aksara, Jakarta; 2010.

3. DepKes RI. Pedoman Prosedur Dan Penyelenggaraan Rekam Medis Di Rumah Sakit Di Indonesia. DepKes RI Dirjen Bina Pelayanan Medik: Jakarta; 2006.

4. Firdaus SU. Rekam Medik Dalam Sorotan Hukum Dan Etika. Surakarta; 2012.

5. Hatta G. Analisis Sistem Pengelolaan Rekam Medis, Jakarta.; 2010. 
6. Rustiyanto Ery. Etika Profesi Perekam Medis Dan Informasi Kesehatan, Yogyakarta: Graha Ilmu.; 2009.

7. Menkes RI. Peraturan Menkes RI No.269/Menkes/III/2008 Tentang Rekam Medis atau Medical Record, Jakarta. Published online 2008.

8. Sugiyono. Metode Penelitian Bisnis. Bandung: Alfabeta. Published online 2013.

9. Notoatmodjo Soekidjo. Promosi Kesehatan Teori Dan Aplikasi. Jakarta: Rineka Cipta; 2010.

10. Nursalam. Konsep Dan Penerapan Metode Penelitian Ilmu Keperawatan. Jakarta; 2008.

11. Ramadhaniyah E, Arif Kurniadi MK. Karakteristik Pengetahuan Dan Sikap Perawat Terhadap Pengisian Kelengkapan Formulir Rm 3 Asuhan Keperawatan Di Rsud Tugurejo Semarang. Kesehat Masy. 2015;3:1-10.

12. Novita Dewi. Tingkat Pengetahuan Tentang Kerahasiaan Dokumen Rekam Medis pada Perawat di Rumah Sakit PKU Muhammadiyah Gamping. Yogyakarta. Published online 2017.

13. Hasibuan AS, Siburian MW, Medan S. Sikap Petugas Terhadap Pengisian Rekam Medis Rawat Inap Di Rumah Sakit Sinar Husni. 2018;(1):363-369.

\section{BIOGRAPHIES OF AUTHORS}

\begin{tabular}{l|l} 
Deni Maisa Putra, Gelar Sarjana diperoleh dari STIKes Ceria Buana Lubuk Basung \\
Jurusan Ilmu Keperawatan 2018 dan Profesi Ners diperoleh dari STIKes Ceria Buana \\
Lubuk Basung Jurusan Ilmu Keperawatan 2010. Magister Ilmu Keperawatan diperoleh \\
dari Universitas Padjadjaran Bandung pada Tahun 2017. Saat ini aktif sebagai Dosen \\
tetap di Program Studi D-3 Rekam Medis dan Informasi Kesehatan STIKes Dharma \\
Landbouw Padang, Sumatera Barat.
\end{tabular}

